\title{
A Composição dos Colegiados da Administração Pública Direta e Indireta
}

\author{
Marília F. de Marsillac
}

\section{INTRODUÇÃO}

Embora há muito existam manifestações que conferem correto equacionamento às Questôes referentes aos colegiados da Administração Pública Direta e Indireta, permanecem incertezas Quanto à possibilidade de integração a esses órgãos daqueles que já têm a condição de agentes púbílicos por titularem cargos, empregos ou funções.

Impasses que dificultam a constituição dos colegiados e seu funcionamento e que se contrapõem aos fins de interesse público visados em sua instituição.

Motivos determinantes do presente estudo, desenvolvido a partir da observação sobre a amplitude dessa forma orgânica de atuação, em suas diferenciadas espécies, as condições exigidas em sua composição, a atuação de seus integrantes em sua temporariedade, na forma de sua remuneração e seus efeitos, com vistas distingui-la de outras formas de investidura.

Desse modo, busca -se demonstrar, com base na interpretação sistemática do ordenamento vigente, a inconsistência dos óbices opostos e sugerir formas de adeQuação em aspectos que possam se tornar críticos, para concluir pela possibilidade de sua superação, na tentativa de viabilizar o adequado atendimento aos interesses públicos, mediante otimização dos melhores recursos humanos e justa remuneração.

Proposta em que se têm como orientação as palavras de Lúcia Valle Figueiredo:

6.2. O nomem juris não Qualifica um instituto. Entretanto, em se considerando o 'usuário' da linguagem, torna-se bastante prejudicial a atribuição de uma 'Qualificaçāo' Que não conote o instituto. Isso porque, funcionando as classificações como sinais, os intérpretes serão induzidos em erro e poderão atribuir ao instituto determinadas características que não lhe pertencem. '

' Empresas Públicas e Sociedades de Economia Mista. São Paulo: Ed. Revista dos Tribunais, 1978, p. 81 . 
E de Manoel Oliveira Franco Sobrinho ao salientar:

São precisamente as razões de fato e de direito antecedentes do ato administrativo que justificam sua finalidade e existência. Razões que resguardam o próprio ordenamento jurídico, Que submetem a Administraçāo e administrado a regras recíprocas de comportamento.

Resulta inquestionável que a finalidade contendo os efeitos há de vir Qualificada in concreto, oferecendo figuração categórica ao ato administrativo, definindo-o na categoria tendo em mira determinado resultado de interesse público. (Grifo nosso.) $)^{2}$

\section{AS DIVERSAS ESPÉCIES DE COLEGIADOS EXISTENTES NA ADMINISTRAÇÃO PÚBLICA DIRETA E INDIRETA}

Definidos os entes e órgãos existentes na administração, sua natureza e seus fins ${ }^{3}$, identificam-se, em sua composição, núcleos com estruturas singulares ou plúrimas que podem ser disciplinados também por normas de direito privado, Quando a administração é descentralizada e atribuída a entidade com personalidade própria, destacada do Estado 4 .

Enquanto os primeiros correspondem a atribuições concentradas (=competência) em cargos, empregos e funções titulados individualmente, os núcleos com estrutura plúrima constituem os chamados colegiados Que, para Lafayette Pondé, são:

[Órgãos ou centros de poder] providos de uma pluralidade de pessoas, tomadas estas como uma unidade funcional, um 'collegium', ou coletividade organizada, contínua, 'individualizada', mantida por um vínculo associativo, cujas decisões

\footnotetext{
Atos Adninistrativos, Săo Paulo: Edição Saraiva, 1980, p. s. 17/18.

Conforme Layete Pondé (in Peculiaridades do órgão colegiado. Revista do Tribunal de Contas do Estado de Săo Paulo no $32,2^{\circ}$ semestre de 1972, p. 122.). No mesmo sentido, Oswaldo Aranha Bandeira De Mello (in Princípios gerais de Direito Administrativo. $2^{a}$ ed., Rio de faneiro: Ed. Forense, 1979, v. 2, p. 7.)

Para Hely Lopes Meirelles, "Órgãos colegiados ou pluripessoais são todos aqueles que atuam e decidem pela manifestação conjunta e mą̧oritária da vontade de seus membros. Nos órgãos colegiados não prevalece a vontade individual de seu Chefe ou Presidente, nem a de seus integrantes isoladamente: o que se impöc e vale juridicamente é a decisão da maioria, expressa na forma legal, regimental ou estatutária. Nas relações com a própria Administração e com terceiros os órgāos colegiados são representados por seus dirigentes, $\mathrm{e}$ não por seus membros, conjunta ou isoladamente. O ato colegial só é necessário para a manifestação da vontade do órgão no desempenho específico de suas funçôes. Assim as Corporaçöes Legislativas os Tribunais e as Comissóes deliberam e decidem por seus plenários e cânaras, mas se fazem representar juridicamente e se administram por seus Presidentes, Chefes ou Procuradores." (Grifo nosso. Direito Administrativo brasileiro.

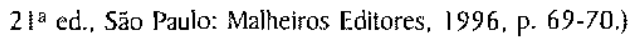

4 Conforme Ruy Cirne Lima. (Princípios do Direito Administrativo, Porto Alegre: Sulina, 1964, p. 147.).
} 
resultam de um processo de elaboração de Que participam as declarações pessoais dos seus componentes, expressas em um momento dado e sob uma forma determinada ${ }^{5}$

Alguns com existência necessária ao funcionamento do ente público ou privado, conforme estabelecido pelo ordenamento, outros legalmente instituídos pelos entes políticos competentes - União, estados, Distrito Federal e municípios, os colegiados - também denominados órgãos de deliberação coletiva - traduzem a tendência atual, ressaltada por Diogo de Figueiredo Moreira Neto, de busca da ponderação e da consensualidade ${ }^{6}$ na prevenção e na composição de conflitos. instituídos:

Colegiados que exercem uma única ou várias funções no ente ou órgão em Que foram

a) de natureza consultiva, em geral de caráter técnico e/ou político, denominados conselhos, comitês, comissões, fóruns;

b) de natureza administrativa, atuando na gestão ou no assessoramento, em geral chamados de conselhos deliberativos, de administração ou comissões;

c) de natureza decisória, com atuação em processos instaurados pelo administrado juntas, consethos ou tribunais;

d) de natureza fiscalizatória, comumente atuando no controle interno sob a denominação de comissôes ou conselhos fiscais.

Em retrospectiva à Constituição de 1934. Themístocles Brandão Cavalcanti, anota Que a formação de conselhos técnicos "deu um sentido novo à composição do Poder Executivo, maior maleabilidade no funcionamento dos departamentos ministeriais", salientando: "Somente por meio de autorização constitucional teria sido, efetivamente, possível dar aos Conselhos a força de veto a certas deliberações administrativas, diante do qual, se devem curvar os Ministros de Estado."?

Atualmente previstos pela Constituição da República Federativa do Brasil - CRFB, com composição e competência ali definidas: os Conselhos da República (arts. 89 e 90), de Defesa Nacional (art. 91) e de Comunicação Social (art. 224), todos com função consultiva e política, os dois últimos também com funções de assessoramento (inciso $\mathrm{IV}$ $\S 1^{\circ}$, do art. 91 e art. 224) ${ }^{8}$. Colegiados integrados somente por agentes políticos, os dois primeiros, enquanto o de Comunicação Social, conforme Lei federal 8.389, de 30/12/91, é composto por técnico

${ }^{5}$ Peculiaridades do órgão colegial. Revista de Direito público, v. 20, p. 25.

- Uma nova administração pública. Revista de Direito Administrativo, v. 220, p. I8I.

7 Tratado de Direito Administrativo. $2^{\text {a }}$ ed. revista e aumentada, Rio de laneiro: Livraria Editora Freitas Bastos, 1948, v. 1, p. 335.

${ }^{8}$ Conforme José Afonso da Silva. (Curso de Diretto Constitucional positivo. $6^{\text {a }}$ ed., $2^{\text {a }}$ tiragem, São Paulo: Editora Revista dos Tribunais, 1990, p. 555-557.). 
na área de comunicação social, representantes da sociedade e de categorias econômicas e profissionais. Prevista no art. 10. "a participação dos trabalhadores e empregadores nos colegiados dos órgãos públicos em Que seus interesses profissionais ou previdenciários sejam objeto de discussão e deliberação".

Embora sem previsão constitucional expressa, deve ser mencionado, pela relevância de suas funções, o Conselho Monetário Nacional, criado pela Lei federal no 4.595 , de 31 de dezembro de 1964, Que, com alterações posteriores, disciplina também suas atribuiçóes e composição.

Ainda de referir, o conselho de política de administração e remuneração de pessoa! a ser instituído pela União, Estados. Distrito Federal e Municípios, a ser composto exclusivamente por servidores públicos, segundo a nova dicção conferida ao art. 39 da CRFB pela EC n ${ }^{\circ} 19$, de $4.06 .98^{\circ}$.

Verifica-se assim a existência de inúmeros colegiados existentes tanto na Administração Direta, vinculados diretamente aos diversos Ministérios e Secretarias ${ }^{10}$, como na Administração Indireta, integrando a estrutura das autareuias, fundaçōes, empresas públicas, sociedades de economia mista, subsidiárias e controladas, Que contam com a participação de agentes intitucionais" ${ }^{\prime \prime}$, servidores públicos, de representantes de grupos profissionais e de vários segmentos da sociedade.

De suma importância no funcionamento das universidades, Qualquer que seja sua natureza - pública ou privada, e nas instituições privadas Que atuam em colaboração com o poder público.

De interesse registrar Que a Constituição do Estado do Rio Grande do Sul, de 03.10.89, nos termos de seu art. 19, adota como um dos princípios da Administração Pública a participação, sendo previstos, inúmeros colegiados Que a asseguram com diferentes finalidades. São os Conselhos: de Defesa e Segurança da Comunidade (art. 126);

- Atualmente sob argüição de inconstitucionalidade nos termos da ADIn 2135; ajuizada em 27/01/00, ainda sem decisão Quanto ao pedido cautelar.

${ }^{10}$ Odete Medauar observa Que, embora muitos consehhos e comissões situem-se na estrutura de Ministérios, Secretarias Estaduais e Municipais, sobre tais órgãos nem sempre incidem todas as conseqüências comuns da subordinação hieráreuica. Em alguns, a eficácia de suas decisões depende de atos de homologação ou de aprovação de uma autoridade superior. Entretanto, esta não pode avocar competência, nem pode delegar, em virtude do caráter especffico das funções desse órgão, por vezes arroladas em lel. Exempliffica citando o Consello de Contribuintes, integrante do Ministério da Fazenda e a este subordinado do ponto de vista organizacional, atuando com independência funcional específica na apreciação e decisăo dos recursos Que the são submetìdos. (Direito Administrativo moderno. $3^{a}$ ed., São Paulo: Editora Revista dos Tribunais, 1999, p. 70-1.).

"Expressão utilizada pelo Auditor do Tribunal de Contas do Estado do Rio Grande do Sul, Substituto de Consetheiro, Professor e Doutor Pedro Henripue Poli de Figueiredo, nos ENCONTROS REGIONAIS DE CONTROLE E ORIENTAÇÄO promovidos por aquele Tribunal nos dias 12,25 e 25 de setembro de 2003, nas Cidades de Santa Cruz, Santa Maria e Erechim, em palestras proferidas sobre o Tema Terceirizaçăo no Serviço Páblico, para designar os agentes públicos integrantes de instituiçóes que têm radical constitucional e disciplinamento em lei orgânica. 
Estadual da Criança e do Adolescente (art. 260, $\$ 2$ ); Estadual de Cultura (art. 225); Estadual de Educação (art. 207 e 209); Estadual do Idoso (art. 260, § $2^{\circ}$ ); Popular, para acompanhamento da ação político-administrativa do Estado $\left(\operatorname{art.1} 19, \S 2^{\circ}\right)$. Com finalidade restrita à formulação da política salarial, previsto pelo $\$ 2^{\circ}$, art. 27 da mesma Carta, órgão "com participação paritária de representantes dos servidores públicos e empregados da administração pública, na forma da lei", e ainda o Conselho Estadual de Ciência e Tecnologia, instituído a partir da previsão constante do art. $235^{12}$.

Relevante a atuação dos colegiados no controle interno da Administração direta e indireta. ${ }^{13}$ Função Que radica não só no disciplinamento específico das entidades, mas no dever de supervisão, conforme expresso pelo art. 26 do Decreto-Lei no 200 , de 25/02/6 $7^{14}$, recepcionado pela $C R F B$ que, no inciso l, parágrafo único, do artigo 87 , reproduz o dispositivo contido no inciso 1 do art. 85 da EC n ${ }^{\circ} 1$, de $17.10 .69^{15}$.

Paralelamente, dispõem, a Constituição do Estado do Rio Grande do Sul Estado, conforme previsão contida no inciso I do art. 90, e o Decreto estadual $n^{\circ} 19.801$, de 08.08.69 ${ }^{16}$, cujo art. $6^{\circ}$ tem teor similar ao mencionado dispositivo do Decreto-Lei $n^{\circ} 200 / 67 .{ }^{17}$

Com funções decisórias, em processos instaurados pelos administrados, destacamse, na área tributária, em âmbito federal, os Conselhos de Contribuintes; em âmbito estadual, o Tribunal Administrativo de Recursos Fiscais - TARF ${ }^{18}$, e em matéria de trânsito, as funtas Administstrativas de Recursos de Infrações - IARIs ${ }^{19}$, dentre outros tantos.

12 Lei estadual $n^{\circ} 10.534$, de 08/08/95.

13 A Lei ñ 4.478 , de 09.01 .63, do Estado do Rio Grande do Sul, que dispóe sobre a administraçäo econômicofinanceira das autarquias, disciplina sua fiscalização interna, atribuindo-a a uma Comissão de Controle (art. 38).

${ }^{14}$ Art. 26 - No Que se refere à Administraçăo Indireta, a supervisão ministerial visará assegurar, essencialmente: 1- A realização dos objetivos fixados nos atos de constituição da entidade. Il - A harmonia com a política $e$ a programação do Governo no setor de atuação da entidade. Ill - A eficiência administrativa. N - A autonomia administrativa, operacional e financeira da entidade.

Parágrafo único - A supervisão exercer-se-á mediante adoção das seguintes medidas, além de outras estabelecidas em regulamento: a) omissis, b) designação, pelo Ministro, dos representantes do Governo Federal nas Assembléias-Gerais e órgãos de administração ou controle da entidade;

${ }^{15}$ Art. 87 - Omissis. Parágrafo único. Compete ao Ministro de Estado, ałém de outras atribuiçó̃es estabelecidas nesta Constituição e na lei: I - exercer a orientação, coordenação e supervisão dos órgäos e entidades da administraçăo federal na área de sua competência e referendar os atos e decretos assinados pelo Presidente da República;

${ }^{16}$ Art. $6^{\circ}$ - Todo órgäo da Administração Direta ou Indireta está suịieito à supervisão do Governador ou do Secretário de Estado em cuja área de atuação estiver enquadrada sua principal atividade. ............. $\S 2^{\circ}$. Além de outras medidas estabelecidas por ato do Chefe do Poder Executivo, a supervisão dos órgãos da Administraçăo Indireta se exerce através de:

II - designação, pelo Secretário de Estado. ouvido o Governador, do representante do Governo nas Assembléias Gerais e nos órgäos de administraçâo e de controle da entidade; No mesmo sentido, 0 art. $2^{\circ}$ da Lel $\pi^{\circ} 10.356$, de 10 de janeiro de 1995 , do Estado do Rio Grande do Sul, regulamentado pelo Decreto $n^{\circ} 35.808$, de 31 de janeiro de 1995.

17 Ainda no Estado do Rio Grande do Sul, a Lei n ${ }^{\circ} 4.478$, de 09.01.63, dispondo sobre a administração econômicofinanceira das autarouias, disciplina sua fiscalização intema, atribuindo-a a uma Comissăo de Conţole (art. 38).

18 Disciplinado pelos artigos 97 a 113 da Lei $n^{\circ} 6.537$, de 27 de fevereiro de 1973, do Estado do Río Grande do Sul.

19 Previstas pelos artigos $7^{\circ}$, inciso VII, e 16. 17 e 285 da Lei federal no 9.503, de 23 de setembro de 1997 - Código de Trânsito Brasileiro. 
De interesse atentar às especificidades próprias dos órgãos colegiados, expressas em sua legislação de regência, em consonância com a finalidade de sua instituição vinculada a do próprio ente que integra, a condicionar sua formatação, composição e funcionamento.

Fora dos padrões gerais, estão os Conselhos Tutelares, disciplinados pela legislação municipal, Que, a par das atividades típicas de colegiados, têm atribuições de natureza executiva e atuação cometida individualmente a seus membros. Atribuições Que thes são peculiares e distintas da atuação dos membros integrantes dos demais colegiados.

Nessa visão panorâmica, ainda útil a prudente observação de, José Gascon Y Marin ${ }^{20}$ :

No hay que censurar la existencia de Cuerpos consultirovs, técnicos o profesionales, originados por el creciente aumento de la actividad administrativa; pero sí conviene no abusar de sua actuación, Que en ciertos casos puede constituir un elemento dilatorio de la acción administrativa. Por ello deben ser limitados los asuntos em Que obligatoramente deban ser ódos los Cuerpos consultivos, y debe ser ejercida con una gran discreción por el órgano activo la facultad de poder oír al Cuerpo consultivo, reducida a los casos en que verdaderamente exista dificultad técnica o jurídica.

\section{A SOCIEDADE DE ECONOMIA MISTA E SEUS COLEGIADOS.}

Especial destaque merecem os colegiados das sociedades de economia mista, porque, sendo esta disciplinada pela Lei societária, comumente não é considerada em suas peculiaridades próprias, determinadas por normas que legitimam o direcionamento conferido pelo acionista controlador para concretização do interesse público definido na lei que autorizou sua criação a que se soma à supervisão exercida pelo Executivo/Ministério ou Secretaria a Que estão vinculadas.

Nessa configuração, salienta-se a função de controle, dos Conselhos Fiscais, ali de existência necessária, como previstos pela Lei federal $n^{\circ} 6.404$, de 15.04.76, e, embora com funçōes distintas, os Conselhos de Administração, de cujo desempenho depende a orientação da companhia, a teor do disposto pelo art. 238, combinado com os artigos I $16 \mathrm{e}$ 117, todos da mesma Lej ${ }^{21}$.

20 Tratado de Derecho Administrativo: princípios da legislación española, $6^{a}$ ed. revisada, Madrid: $[935$, t., p. 283.

${ }^{21}$ Art. 238 - A pessoa jurídica que controla a companhia de economia mista tem os deveres e responsabilidades do acionista controlador (artigos 116 e 117), mas poderá orientar as atividades da companhia de modo a atender ao interesse público que justificou a sua criação.

[Art. I 6 - Entende-se por acionista controlador a pessoa. natural ou jurídica, ou o grupo de pessoas vinculadas por acordo de voto, ou sob controle comum, que: 
Sobre tais disposições, esclarecedora é a análise de losé Edwaldo Tavares Borba Que, após ressaltar a impossibilidade de serem estabelecidas "normas especiais que excepcionem a lei geral das sociedades anônimas", aduz:

Convém, todavia, distinguir um campo de relações inteiramente aberto ao disciplinamento especial, Que é o das relações entre o Poder Público controlador e as administraçóes das sociedades sob seu controle. Ao disciplinar essa matéria, agirá o Poder Público como Qualquer empresário privado que detenha o controle de um conjunto de empresas e Que, por isso mesmo, precise manter um sistema de acompanhamento permanente e ordenado.

Nessa linha de entendimento estruturou-se a supervisão ministerial, ou, no eue concerne aos estados e municípios, a supervisão dos secretários e do próprio governador ou prefeito.

A supervisão insere-se no nível das relações internas de natureza administrativa e pode comportar normas muito particulares, desde que respeitados os princípios e regras consagrados na legislação das sociedades anônimas.

Essas normas, Quando de caráter permanente, poderão ser definidas em lei ou decreto. Não serão normas de direito mercantil, mas sim de direito administrativo, uma vez Que se destinam a regular as relaçōes entre o Poder Público controlador e a administração da empresa. Equivaleriam às instruções e regulamentos baixados por um empresário privado. Funcionam como recomendaçöes dirigidas aos administradores das várias sociedades sob o comando daquele controlador. Poderão, por conseguinte, ser produzidas em Qualquer esfera de governo Poderão, por conseguinte, ser produzidas em Qualquer esfera de governo (federal, estadual e municipal), mesmo porque não integram o direito mercantil, este reservado, com exclusividade, à competência da União (art. 22, I, da Constituição Federal)." (Grifo nosso.). ${ }^{22}$

a) é titular de direitos de sócio que the assegurem, de modo permanente, a majoria dos votos nas deliberaçóes da assembléła geral e o poder de eleger a maioria dos administradores da companhia; $\mathrm{e}$ b) usa efetivamente seu poder para dirigir as atividades sociais e orientar o funcionamento dos órgãos da companhia.|

Art. 239 - As companhias de economia mista terăo obrigatoriamente Conselho de Administraçăo, $[\ldots]$.

Art. 240 - O funcionamento do Conselho Fiscal será permanente nas companhias de economia mista, [...]."

27 Direito societário. $3^{a}$ ed. revista e atualizada, Rio de Janeiro: Freitas Bastos Editora, 1997, p. 363/4. Aspectos detidamente examinados nos Pareceres PGE nos 8.371/90 e 12.864/00, firmados pelas Procuradoras do Estado do Rio Grande do Sul Eliana Donatelli. Del Mese e Denise Vargas Amorim, respectivamente, disponiveis no site <http:/Www.pge.rs.gov.br >. 
No mesmo sentido, Celso Antônio Bandeira de Mello:

Os dirigentes das sociedades de economia mista investidos em decorrência de providências governamentais, exercidas em nome da supervisão ministerial, na forma do art. 26, parágrafo único, letras ' $a$ ' e 'b' (do Decretolei 200/67), normalmente exercem, em tais pessoas, mandatos, representantes que são do Poder Público no interior da entidade mista.(...)

Com efeito, em alguns casos são diretamente nomeados pelo Governo e em outros eleitos pelo Estado acionista majoritário, mas, em Qualeuer hipótese, o controle estatal (de que são um dos veículos) não é instituído apenas em nome do bom sucesso da empresa mas, e sobretudo, em nome da harmonizaçẫo do comportamento da sociedade de economia mista como planejamento administrativo global do Governo. ${ }^{23}$

Aspectos assim enfocados por losé Cretella |r., citando Ernest Forsthoff (Tratado de Derecho Administrativo, ed. espanhola, I958, p. 669):

"Do ponto de vista do direito Administrativo, la sociedade de economia mistal só pode ser estudada na medida em Que se observa a influência Que pode exercer, na sua gestão, o órgão administrativo participante, em virtude dos direitos sociais Que the correspondem. Sob a forma deste tipo de influência, ou dito de modo mais preciso, da participação na direção empresarial, não apenas na participação do capital, surge o caráter peculiar de economia mista de tal empresa".

Adiante, referindo extensa bibliografia nacional, acrescenta: "É necessário Que, além de subscrever parte, maior ou menor, ou mesmo, Quase a totalidade do capital da sociedade, o Estado participe de modo ativo, na vida e nas realizaçốes da empresa, $[. . .]^{\text {24 }}$

E Maria da Conceição do Amaral Monch ressalta:

Quando o Estado detém a maioria das ações de uma sociedade de economia mista, ele, em razão da preponderância financeira e administrativa acentuada, nomeia os administradores da empresa e a dirige na realidade. prevalecendo o interesse público sobre o privado, através do controle dos serviços pelos prepostos do Estado, através de administração estatal Que existe, embora indireta. (Grifo nosso.). ${ }^{25}$

23 Prestação de serviços públicos e Administração indireta. Săo Paulo: Ed. RT, 1973, p. 119-121.

24 Direito Administrativo brasileiro. 2a ed., Rio de laneiro: Forense, 2000 , p. 164 c 169.

25 As sociedades de economia mista e as empresas públicas: controle e responsabilidade. Revista de Direito Administrativo, Rio de laneiro, v.127, p.574, janeiro-março, 1977. 
No Estado do Rio Grande do Sul, preceituação introduzida por Emenda Constitucional ${ }^{26}$, cobra a efetividade do poder de gestão titulado pelo acionista controlador nas sociedades de economia mista.

\section{A NATUREZA DA PARTICIPAÇÃo NOS ÓRGÃOS DE DELIBERAÇÃo COLETIVA}

Em todos os colegiados, é ínsito o relevante interesse público das atribuições assumidas por seus membros, caracterizadas como múnus público ${ }^{27}$, ainda Quando exercem tal atividade em caráter profissional e mediante remuneração. ${ }^{28}$

De interesse registrar que o conceito de 'múnus público' surgiu com a civilização romana, significando a honradez com que a atividade pública deve ser desempenhada, vez Que, necessariamente, aquele que age em beneficio da coletividade tem de se submeter aos ditames éticos e jurídicos imprescindiveis à realização do bem comum.

Do Que resulta estarem investidos nesse múnus, além dos agentes institucionais e agentes administrativos, em decorrência de suas próprias atribuições nas posições tituladas, - Qualificando-as e obrigando a uma conduta compativel com os fins determinantes de sua atividade -, também aqueles que vêm a colaborar com o poder público, dentre os quais se encontram os membros dos órgãos de deliberação coletiva.

Oswaldo Aranha Bandeira de Mello salienta Que, em tal condição, tais agentes "não são órgãos da administração, mas em conjunto, na assembléia ou agrupamento de Que são membros"29, e Lafayette Pondé, em análise às decisões do Tribunal de Contas e às resoluções de Conselho Universitário, determinadas pelo voto adotado pela maioria dos respectivos membros, reunidos em sessão, salienta Que:

Nenhum destes membros, porém, é 'órgão' do Estado. Órgão único é o Tribunal, é o Conselho da Universidade, cada qual provido por uma

${ }^{26}$ Emenda Constitucional $n^{\circ} 31$, de 18.06.02, acrescentou dispositivos os $\S \S 2^{\circ}$ e $3^{\circ}$ ao artigo 22 da Carta Estadual: $\S 2^{\circ}$ - Especialmente no caso das Sociedades de Economia Mista Banco do Estado do Rio Grande do sul S.A. e Companhia Riograndense de Saneamento, a alienação ou transferência do seu controle acionário, bem como a extinção, fusão, incorporação ou cisão dependerá de consulta popular, sob a forma de plebiscito. $\$ 3^{\circ}$ - Nas sociedades de economía mista, en que possuír o controle actonário, o Estado fica obrigado a manter o poder de gestão, exercendo o direito de maioria de votos na assembléia geral, de eleger a maioria dos administradores da companhia, de dirigir as atividades sociais e de orientar o funcionamento dos órgãos da companhia, sendo vedado Qualquer tipo de acordo ou avença que implique em abdicar ou restringir seus direitos. (Grifo nosso.)

${ }^{27}$ Conforme Hely Lopes Meirelles. (Direito Administrativo brasilleiro. 2 I $^{2}$ ed., São Paulo: Malheiros Editores, 1996 , p. 75.).

${ }^{28}$ Registra Aurélio Buarque de Holanda Ferreira: "Múnus público. O que procede de autoridade pública ou da lei, e obriga o individuo a certos encargos em beneficio da coletividade ou da ordem social." (Novo dicionário Aurélio da língua portuguesa, $2^{\mathrm{a}}$ ed. revista e ampliada, Rio de laneiro, 1986, p. 1172.).

${ }^{29}$ Princípios gerais de Direito Administrativo. $2^{\text {a }}$ ed., Rio de lanciro: Ed. Forense, 1979, v. 2, ps 288-290. 
'organização unitária'. Seus membros, nenhum deles exerce a atribuição incluída na competência do respectivo órgão. Todos ocupam uma posição meramente instrumental, de contribuir tão-só para formar a maioria deliberante sobre matéria daquela competência ${ }^{30}$

Assumindo essa condição de membros integrantes de colegiados, e sendo inexistente prévia vinculação com a Administração pública Direta ou Indireta, as pessoas designadas ou eleitas para integrar os colegiados vêm a compor a categoria dos chamados agentes honoríficos, Que, conforme Hely Lopes Meirelles, abrange:

[...] os cidadãos convocados, designados ou nomeados para prestarem, transitoriamente, determinados serviços ao Estado, em razão de sua condição cívica, de sua honorabilidade, ou de sua notória capacidade profissional, mas sem QualQuer vínculo empregatício ou estatutário e, normalmente, sem remuneração, $[. . .]^{31}$

Acrescentando:

Os agentes honoríficos não são funcionários públicos, mas momentaneamente exercem uma função pública e enquanto a desempenham, sujeitam-se à hierarquia e disciplina do órgão Que estão servindo, podendo perceber um pro labore [...]. Sobre estes agentes eventuais do Poder Público não incidem as proibiçôes constitucionais de acumulação de cargos, funções ou empregos (art. 37, XVI e XVII) poreue a sua vinculação com o Estado é sempre transitória e a título de colaboração cívica, sem caráter empregatício. Somente para fins penais é Que esses agentes são equiparados a funcionários públicos Quanto aos crimes relacionados com o exercício da função, nos expressos termos do art. 327 do CP. ${ }^{32}$ (Grifo nosso.)

Do mesmo modo, Oswaldo Aranha Bandeira de Mello definira:

Os (agentes) honoríficos são os titulares acidentais de determinados cargos da alta administração, de caráter honroso, desempenhados ocasionalmente, como colaboradores da ação dos governantes, aconselhando ou decidindo a respeito de Questões de superior interesse da coletividade, a serem, em regra, ordenadas por aqueles. São, por exemplo, os Membros do Conselho de Impostos e Taxas, do Conselho de Comércio e Finanças, do Conselho Penitenciário, os jurados, etc. (...) em geral, exercem o serviço público em

30 Peculiaridades do órgão colegial. Revista de Direito público, v. 20, p. 28.

${ }^{31}$ Hely Lopes Meireltes

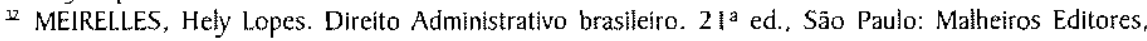
1996 , p. 75. 
colégio, e assim, pessoalmente, na consecução das atribuições dos cargos, não são órgãos da administração, mas, em conjunto, na assembléia ou agrupamento de Que são membros. [...] os cargos honoríficos não exigem dos seus titulares que se consagrem principalmente a eles, visto Que os seus serviços são levados a efeito de intervalos a intervalos de tempo, em certas e determinadas ocasióes, por horas restritas de atividade, para o seu desempenho, Quando chamados por órgãos competentes. Por essa razão, os cargos públicos honoríficos, de regra são gratuitos, percebendo apenas em aliguns casos, os agentes públicos, por sessão realizada, certa importância a título de indenização. É o jeton. ${ }^{33}$ (Grifo nosso.)

lá Quando os designados ou eleitos têm prévia vinculação à Administração Direta ou Indireta, na condição de agentes institucionais ou servidores públicos, necessário distinguir a natureza desse vínculo, a natureza dos colegiados Que integrarão e a existência ou não de disciplinamento permissivo dessa participação e da correspondente remuneração.

Genericamente, sendo a atuação dos agentes institucionais ou servidores imprescindivel ao próprio funcionamento do colegiado - disciplinada legalmente a partir dos fins de interesse público Que determinaram sua instituição -, possível sua caracterização como comissão legal, segundo a conceituação de Ruy Cirne Lima, Que, após diferenciá-la dos cargos providos em caráter precário, registra:

[...] entende-se como comissão, também, a tarefa estatal, de natureza execpcional e duração limitada, não ligada, por isso mesmo, a cargo público, de natureza permanente e com atribuições ordinárias. Nesta última acepção, há de entender-se a comisssão, Que a Constituição proíbe aos membros do Poder Legislativo aceitarem ou exercerem, desde a expedição do diploma (art. 48, I, b, Const. Fed. ${ }^{34}$ ). Vem-nos o termo, com esta significação, de nosso direito antigo. 'Também significa a palavra comissão - escreveu Pereira e Souza - a jurisdição conferida, extraordinária, a alguém sobre certos objetos'. ${ }^{35}$

33 Princípios gerais de Direito Administrativo. $2^{a}$ ed., Rio de laneiro: Ed. Forense, 1979, v. 2, p. 288-290.

34 "Os deputados e senadores não poderão: aceitar nem exercer comissão ou emprego remunerado de pessoa jurídica de direito público, entidade autárquica, socledade de economia mista ou empresa concessionária de serviço público;" Constituição da Repúbíca dos Estados Unidos do Brasil, de 18.09.46. Vedação similar à constante da alínea b, inciso 1 do art. 54 da Constítuição da República Federativa do Brasil, de 5 de outubro de 1988 ,

35 Prìncípios de Direito Administrativo. Porto Alegre: Livraria Sulina Editora, 1964, ps. 178-179. Nota 35 - Pereira e Souza, Dicionário lurídico, t. 1, Lisboa, 1825, verb. Comissão. 
Também de Plácido e Silva registra:

COMISSÃO - Derivada do latim commissio, de commitere, significa não somente a ação de unir, concurso, como também a ação de confiar, de entregar. E nesse duplo sentido de união ou concurso para um fim determinado ou de auxlijo cooperaçãona execução de determinados misteres, possui o vocábulo, na linguagem jurídica, uma variedade de acepções.

Comissão. No sentido que the empresta o Direito Público Administrativo e o Direito Internacional, é o vocábulo empregado:

a) Para indicar todo encargo ou atribuição confiada ao empregado ou funcionário público efetivo, em virtude de sua investidura em cargo ou função Que não é a própria. ${ }^{36}$

Caracterização que se acentua Quando, por expressa determinação legal, o colegiado deva ser integrado por determinada categoria de agente público, em razão das atributções do cargo ou função que ocupa na origem ou como representante de sua classe ou categoria (ex: a participação de integrante do Ministério Público no Conselho Penitenciário; de integrantes da polícia rodoviária nas |ARIs; de representante de servidores, no Conselho de Administração do órgão gestor de seu regime previdenciário, etc. $)^{37}$

De modo similar, o art. 472 da Consolidaçẫo das Leis do Trabalho estabelece Que " $O$ afastamento em virtude das exigências do serviço militar, ou de outro encargo público, não constituirá motivo para alteração ou rescisão do contrato de trabalho por parte do empregador.", prevista, no $\S 1^{\circ}$ do mesmo artigo, a prévia ciência do empregador ${ }^{38}$. Norma

${ }^{36}$ Vocabulário Jurídico, Rio de Janeiro: Forense, 1984, v. I, p. 463. Entendimento também inanifestado por Alaim de Almeida Carneiro (Cargos em comissão. Revista de direito Administrativo, v. 17 , julho-setembro - 1949, p. 71), e José Cretella Ir. (Comentários à Constituiçẫo de 1988. 2a ed., Rio de laneiro: Forense Universitária, 1994, v. 9, p. 4727).

Eduardo García de Enterría em perspectiva histórica, analisa a atuação do comissário como nova técnica administrativa, salientando: "En vez del carácter permanente del oficial, el comisario es esencialmente eventual, em cuanto Que su papel se reduce al cumplimiento de uma 'comisión'. El comisario no ejerce competencias propias, sino competencias del Rey cuyo simple ejercicio le ha sido delegado [...]. No está la comisión constituída por una ley o por un edicto que haya estabelecido objetiva y permanemte un centro de atribuiciones, sino Que la comisión procede de un mandato específico $[. .$.$] ; no es irrevocabele, sino revocable$ ad nutun[...]" (La organizacion y sus agentes: revisión de estructuras in La administración pública y el estado contemporaneo, Instituto de Estudios Politicos, Madrid: 1961, p. 178.).

37 Esse encargo é admitido pela Lei Complementar $n^{\circ}$ 10.098, de 03.02.94 - Estatuto e Regime Jurídico Único dos Servidores Públicos Civis do Estado do Rio Grande do Sul, ao esiabelecer:

Art. 178 - Ao servidor é proibido: $[. ..] \mathrm{X}$ - exercer ou permitir que subordinado seu exerça atribuições diferentes das delinidas em lei ou regulamento como próprias do cargo ou função, ressalvados os encargos de chefia e as comissōes legais. [... Att. 266: "Do exercício de encargos ou serviços diferentes dos definidos em lei ou regulamento, como próprio do seu cargo ou função, não decorre nenhum direito ao servidor, ressalvadas as comissöes legais. (Grifo nosso.)

38 Aspectos analisados nos Pareceres PGE nos. $10.175 / 94$ e $8.756 / 91$, disponíveis no site <http:// www.pge.rs.gov.br $>$. 
Que tem incidência tanto para os empregados da Administração Direta como da Indireta. Cumpre consignar que, em geral, a designação ou eleição é precedida de consulta ao servidor e de sua aquiescência, que se faz imprescindível quando, na origem, o servidor tem vínculo contratual, sob pena de caracterizar-se indevida alteração do ajuste laboral, caso em que se torna conveniente colher sua manifestação por escrito.

\section{OS FATORES OUE CONDICIONAM A PARTICIPAÇÃO}

Havendo liberdade de escolha, esta tanto pode recair em pessoas estranhas à Administração Pública, como incidir sobre aqueles que já têm a condição de agentes públicos.

Porém, tanto em razão dos fins definidos por cada ente ou órgão da Administração Pública direta e indireta como dos princípios constitucionais da eficiência e da moralidade Que a submetem, imprescindivel a habilitação e a Qualificação pessoal de seus integrantes em sua área especílica de atuação, compreendendo o conhecimento técnico aliado à experiência e a condiçôes morais de idoneidade.

Relevante, em alguns casos, a heterogeneidade na composição dos colegiados, em outros, a homogeneidade na habilitação.

Massimo Severo Giannini distingue também como critério eletivo a 'representação' da 'representatividade ${ }^{* 39}$, acentuando que a composição desses órgãos é determinada pelo desempenho das funções específicas ou múltiplas atribuídas ao órgão.

José Gascon Y Marin ${ }^{40}$ observa Que vários são os sistemas adotados para a organização dos corpos deliberantes: a eleição, a designação ou o sistema misto, acrescentando:

Depende la adopción de uno u outro sistema de la naturaleza asignada al cuerpo deliberante. Si éste tiene carácter representativo, es natural Que se acuda a la elección, medio adecuado para designar representantes; [...] podrá la elección ser directa o indirecta, a base tan sólo de elemento individual o con parte designada por los elementos sociales.

Aduz que, se a finalidade do corpo deliberante há de ser exclusiva ou predominantemente técnica, deverá ser adotado o sistema de designação dos indivíduos que sejam considerados mais aptos, combinando-se os sistemas, no segundo caso. Já nas hipóteses em Que os próprios interessados devem ser os Que administram os interesses comuns ou serviços que aos mesmos ser refere, então justifica-se a eleição, bem como a existência de

39 GIANNINI, Massimo Severo. Insituzioni di Diritto Amministrativo. Milano: Dott. A. Giuffrè Editore, 1981, p. 81 .

40 Tratado de Derecho Administrativo: princípios da legislación española, $6^{\text {a }}$ ed. revisada, Madrid: 1935, t. J, p. $277-278$. 
outros designados pela Administração de esfera superior, conforme a maior ou menor intervenção por esta visada. Anota ainda a possibilidade da existência de membros natos: "individuos designados, no a título personal, sino en virtud de otros cargos o funciones principales." No mesmo sentido Manuel Maria Diez ${ }^{41}$. Nesse caso, necessária a manutenção da condição prévia e necessária estabelecida pelo disciplinamento aplicável, cuja perda determina a substituição do membro no colegiado.

Ewan Ferlie et al anotam Que a substituiçăo de representantes eleitos por representantes locais nomeados, com papel estratégico mais ativo, para alguns, favorece o envolvimento de profissionais experientes e especializados com a administração do serviço público, enquanto os críticos dessa forma de composição "apontam para a natureza não representativa e não responsável desse grupo de liderança. Todos concordam Que essa é uma área importante para a pesQuisa empírica, não obstante serem escassos os dados empíricos sistemáticos." ${ }^{\text {22 }}$. Observam ainda que os colegiados constituem também "grupos de interesse porque eles podem com freqüência ser vistos como grupos heterogêneos e de múltiplos papéis", por integrarem representantes de vários grupos.

De ressaltar a necessidade de serem observadas as prescrições normativas referentes às condições pessoais, inclusive Quanto à sua habilittação e verificação da inocorrência de impedimentos. Assim, relevante a vedação expressa constante do $\S 2^{\circ}$ do art. 162 da Leí federal $n^{\circ} 6.404 / 76$, de empregados da sociedade integrarem seu Conselho Fiscal.

Entretanto, cumpre ressalvar Que a condição de os membros do Consehho de Administração serem acionistas da companhia, estabelecida no art. 146 da mesma Lei, é inaplicável à sociedade de economia mista, não estando o poder público, na condição de acionista controlador, adstrito a transferir ações a seus representantes, como analisado por Modesto Carvalhosa ${ }^{43}$ :

Outra Questão Que se põe diz respeito à necessidade de os conselheiros nomeados pelo Poder Público serem acionistas. Em princípio deveriam sê-lo, em razão dos arts. 146 e 235 . Ocorre Que os conselheiros nomeados pelo Poder Público revestem-se da Qualidade de agentes públicos, com a função de representar o interesse público envolvido nessa atividade empresarial. A propósito, Paulo B. de Araújo Lima: "(...) A autoridade, ainda que detentora de ações, ao comparecer ao consetho, projetara sempre a vontade do Estado e não a sua.".

41 Derecho Administrativo, Buenos Aires: Bibliográfica Omeba, 1963, p. 195.

42 A nova administração pública em ação. Brasilia: Editora Universidade de Brasília: ENAP, 1999, p.54.

${ }^{43}$ Comentários à Lei de Sociedades Anôninas. ed. revista e atualizada, São Pauło: Editora Saraiva, 1998, v. 4, t. I, p. 394-5. Ver também Parecer PGE 12.864/00, de lavra da Procuradora do Estado do Rio Grande do Sul Maria Denise Feix, disponivel no site $<$ http://Mww.pge.rs.gov.br $>$. 


\section{A DURAÇÃo Do MANDATO}

Para determinação do período de investidura como membro integrante do colegiado, relevante a identificação de sua causa determinante, isto é, se ela resulta de designação ou de eleição. Assim, Celso Antônio Bandeira de Mello, nos termos do excerto transcrito (v. item I) e Hely Lopes Meirelles ao destacar:

Merece, ainda, distinção entre o eleito para integrar um colegiado ou para dirigi-lo, e o que é nomeado para o mesmo órgão pelo Executivo: aquele exerce um mandato administrativo, este, uma delegação administrativa da própria Administração, e por isso mesmo pode ser destituído da função sumariamente e a QualQuer tempo pelo delegante, embora a renovação de colegiado tenha prazo certo." ${ }^{44}$

Análise Que deve ser acrescida com o exame das funções do colegiado, conforme interpretação desenvolvida ao influxo de inúmeros litígios ${ }^{45}$.

As divergências sobre o tema ganharam vulto ao tempo do regime militar pela falta de motivação de vários atos de afastamento ${ }^{46}$ Que, suscitados em ações mandamentais, não foram apreciados por dependerem de instrução probatória.

O entendimento firmado pelo Supremo Tribunal Federal, em sessão plenária de 17/ 11/62, no julgamento, do MS no 8.693, Relator Ministro Ribeiro da Costa, fol resumido em ementa do seguinte teor:

Os membros Que representam o Governo no Consetho Administrativo do Instituto de Aposentadoria e Pensões, para ele nomeados em razão de confiança, não têm direito líquido e certo de permanecer no cargo até ofim do mandato, podendo, pois, ser exonerados, se não mais merecerem confiança. ${ }^{47}$

Seguiu-se jurisprudência conducente à conclusão formulada pela Procuradora do Estado do Rio Grande do Sul Rosa Maria de Campos Aranovich, ao enfocar a sizuação do Conselho Penitenciário, no Parecer PGE n 8.900/91:

${ }^{44}$ Direito Administrativo brasileiro. 2 I $^{a}$ ed., São Paulo: Malheiros Editores, 1996, p. 77.

45 STF: RE 24.432-DF; Mandados de Segurança $n^{\circ}$ S.: $8.693,8.778,8.861,8.787,8.815,8.884$, 8.929,9.023, MS 8.884-DF, 9.997.

46 Pelo Ato Institucional $n^{\circ} 5$, de $13 / 12 / 68$, foram exclú́dos de apreciação judicial todos os atos ali previstos, abrangendo aQuetes arrolados no $\S 1^{\circ}$ de seu art. $6^{\circ}$, concernentes a medidas excepcionais de afastamento de pessoal da Administração Direta e Indireta, referido pelo STF, em sessão plenáłła, no acórdão referente ao MS 19.227-DF, de 09/04/69.

${ }^{47}$ Conselho Administrativo de Instituto - representaçăo do governo - mandado de segurança. Revista Forense, vol. 202, 1963, ps. 111-137. Em sentido contrário: 1. Guimarães Menegale. Conselho Administrativo da Caixa Econômica Federal - mandato por nomeaçäo, do Presidente - sua coincidência com o dos conselleiros - indemissibilidade "ad nutum". Revista Forense, v. 193, 1961, ps. 1|1-6. 
Interpretando as decisões do Supremo Tribunal, o deslinde da Questão depende da natureza do cargo ou função a ser desempenhada. Assim se o órgão é de natureza meramente administrativa, a investidura a prazo certo marca o prazo final, mas permite a livre demissão pelo titular da competência para nomear, observada, se for o caso, a conjugação de vontades Quando dela depender o ato. Nos demais casos em cue há relativa autonomia do mandato, o poder de demitir só é possível se a lei confere.

E destacando o voto do Ministro Thompson Flores no voto condutor do acórdão referente ao MS $n^{\circ}$ 19.493 DF, prolatado em 21/05/69 ${ }^{48}$, a Parecerista esclarece:

Nos órgãos administrativos judicantes (Conselhos de Contribuintes, etc.), o exercício da funçäo por prazo certo (mandato) resguarda a independência do julgador. Nos demais, apenas visa a assegurar o princípio moralizador da rotatividade no desempenho de certas funçóes, notadamente aquelas Que se identificam com gestôes financeiras ou patrimoniais. O mandato, então, está a significar Que o prazo não poderá ser excedido; nunca Que não possa ser encurtado, a critério do Poder e Autoridade próprias.

Em 02/08/01, o ST], em acórdão de sua $5^{\text {a }}$ Turma, referente ao MS n ${ }^{\circ}$ [1 .981 -MT, concedeu a segurança a membro de Junta Comercial, representante da $\mathrm{OAB}$, por esta substituído injustificadamente, isto é, sem embasamento nas hipóteses legais para tanto previstas, com base em precedente do mesmo Tribunal ${ }^{49}$.

Portanto, ainda Que vencidas as maiores vacilações, aspectos específicos ainda suscitam aprofundamento do tema e ampliação da abordagem. ${ }^{50}$

\section{A REMUNERAÇÃO DOS MEMBROS DE COLEGIADOS}

Inexistindo tratamento uniforme Quanto à remuneração de membros de colegiados, conforme salientado por Hely Lopes Meirelles e Oswaldo Aranha Bandeira de Mélo (v. item 2), essa é condicionada à legislação de regência daqueles que já integram a Administração Pública Direta ou Indireta e ainda às normas Que instituem e disciplinam os referidos órgãos.

Dessa forma, verifica-se Que os conselhos e comissões vinculados à Administração Direta federal, em Que a participação é definida como encargo público relevante, têm prevista a gratuidade da participação de seus servidores, em consonância com o disposto pelo art. 119, caput, da Lei federal no 8.112 , de 11.1.90, - Regime único dos servidores públicos civis da União, das autarQuias e das fundações públicas federais.

\footnotetext{
${ }^{48}$ Revista Trimestral de jurisprudência, v. 56, 1971. ps. 680-5.

${ }^{49}$ MS 1.480-0-MA.

5o Pareceres PGE no ${ }^{\circ}$. 12.985/01, 12.571/99, 12.505/99, 12.459/99, 9.904/93, disponíveis no site <http://www.pge.rs.gov.br >.
} 
Themístocles Brandão Cavalcanti no acórdão referente ao MS 18.697-DF, de 21 / $05 / 69$, registra a origem e a natureza da remuneração:

[... |criada pelo Estado francês no tempo de Luís XIII, isto é, em 2 de fevereiro de 1625, Que instituiu o jéton d'argent para os Que comparecessem às sessões da Academia Francesa, substituído depois por Colbert em 1683. pelo jéton de presence (em 8 de janeiro).

[...] No Vocabulaire /uridique de Henri Capitant, se encontra uma boa definição jurídica:

"Importância atribuída a pessoas Que assistem a certas sessōes ou assembléias, ou a título de remuneração das funções Que ali exercem, ou a título de retribuição de despesas."

No Brasil foram introduzidas, segundo parece, no serviço público, para os Conselhos de Contribuintes.

No mesmo julgado, define:

E ainda aQui convém fixar bem a natureza dessa retribuição pecuniária Que. nada mais é do Que uma gratificação, como a Qualifica o estatuto dos funcionários públicos (art. 145, IX) pela participação em órgãos de deliberação coletiva [Lei federal $n^{\circ} 1.711$, de 28 de outubro de 1952].

Seria efetivamente uma gratificação em sentido próprio se o titular já fosse funcionário, mas não o será se não for funcionário. (Grifo nosso.)

Consagrado o entendimento sobre o tema expresso por Hely Lopes Meirefles, Que classifica como

Gratificação de serviço (propter /aborem) aQuela Que a Administração institui para recompensar riscos ou ônus decorrentes de trabalhos normais executados em condições anormais de perigo ou de encargos para o servidor, como pela prestação de serviços extraordinários, fora do expediente, da sede ou das atribuições ordinárias do cargo.

Salientando:

Essas gratificaçōes só devem ser percebidas enQuanto o servidor está prestando o serviço Que as enseja, porQue são retribuições pecuniárias pro labore faciendoe propter laborem. Cessado o trabalho Que lhes dá causa ou desaparecidos os motivos excepcionais e transitórios Que as justificam, extingue-se a razâo de seu pagamento. Daí por Que não se incorporam 
automaticamente ao vencimento, nem são auferidas na disponibilidade e na aposentadoria, salvo Quando a lei expressamente o determina, por liberalidade do legislador. ${ }^{51}$

Contrariamente ao Que dispõe o Estatuto Federal, gratificaçẫo com essa natureza é prevista pelos artigos 85 , inciso III, e 122 da Lei Complementar $n^{\circ} 10.098$, de 03 de fevereiro de 1994, Que dispõe sobre o Estatuto e regime jurídico único dos servidores públicos civis do Estado do Rio Grande do Sul, estando seu valor disciplinado pela Lei estadual $n^{\circ} 7.369$, de 18 de abril de 1980, com subseqüentes alterações ${ }^{52}$, para todos os colegiados da entidade política e respectivas autareuias.

Dessa forma, embora tenha tido por vezes a caracterização como verba indenizatória, ou de representação, o entendimento atual é de que o jeton possui natureza remuneratória, como afirmado também pelo Ministério da Fazenda, em apreciação ao processo $n^{0} 200.678-60^{53}$.

Nos entes dotados de personalidade de direito privado da Administração Indireta, a remuneração dos integrantes de seus diversos conselhos deve ser disciplinada nas respectivas normas estatutárias, embora sejam de necessária observância os parâmetros estabelecidos pela legislação federal aplicável. Nas sociedades de economia mista, aplicáveis as disposições específicas contidas na Lei federal $\pi^{\circ} 6.404$, de 15/12/76 $6^{54}$.

Em âmbito federal, a Lei 9.292 , de $12 / 07 / 96$, ao dispor sobre essa remuneração mensal, conferiu nova redação ao parágrafo único do art. 119 da Lei no 8212/90, e assim excepcionou a vedação expressa de remuneração pela participação em órgão de deliberação coletiva, revogando a Lei $n^{\circ} 7.733$, de 14 de fevereiro de 1989 , Que vedava o pagamento pela participação de servidores públicos federais em colegiados de empresas estataís ${ }^{55}$

51 Direito Administrativo brasileiro. $21^{\text {a }}$ ed., São Paulo: Malheiros Editores, 1996, p. 417.

\$2 Normas disponíveis no site http://wwwal. rs.gov.br.

53 Imposto de renda "jeton" de presença - diárias. Revista de Direito Administrativo, v. 73, p. 37 I, 1963.

${ }^{4}$ Apontado, nos Pareceres PGE no 9.002/9 I e 9.635/93, de lavra das Procuradoras do Estado do Rjo Grande do Sul Carita Galbinski e Rosa Maria Aranovich, respectivamente, que, nas companlias, a remuneração dos conselheiros é estabelecida em bases fixas e segue os parâmetros de rcajuste adotados para os dirigentes, enquanto no segundo é lembrado que esta remuneraçãa "tem sido estabelecida pelas próprias entidades em percentagem incidente sobre o valor da reınuneração dos diretores, pré-fixada pelo Clıef́c do Executivo, respeitada obviamente, a competência dos órgáos internos, como é o caso da assembléia geral nas sociedades anônimas", consoante preceituado pelos artigos 152 c 162, \$30, da Lei 6404/76.

5s Art. $1^{\circ}$ - A remuneração mensal devida aos membros dos Conselhos de Administração e Fiscal das empresas públicas e das sociedades de economia mista federais, bem como das demais entidades controladas direta ou indiretamente pela União, náo excederá, con nenhuma hipótese, a dez por cento da remuneração merisal média dos diretores das respectivas empresas.

$\S 10$ - A remuneração só será devida ao membro suplente do Conselho fiscal no mês em Que comparecer a reuniōes do consetho a Que pertencer, conforme registro em ata, no huro próprio. 
Útil na interpretação dos dispositivos em exame, o conhecimento da justificativa ao respectivo projeto de lei, do seguinte teor:

[...]2. A atenção devotada aos ditos conselhos [de administração e fiscal] deriva do fato de que eles se erigem como indispensável instrumento para a execução dos programas gerais e setoriais do Governo, pois, enquanto ao de administração cabe, precipuamente, a orientação estratégica dos negócios empresariais, ao fiscal compete o conseqüente controle do fiel cumprimento dessas estratégias.

3. Vê-se, pois, Que as atividades de planejamento e controle governamentais, ora em revigoramento no âmbito da Administração Pública Federal, conduzem os membros desses conselhos a assumir responsabilidades que extrapolam os limites das funções usuais. Essa importância confirma-se, mais e mais, uma vez Que o Estado vem consignando, em sucessivos normativos, rol de atribuições que os colocam, com propriedade, na condição de elo de coordenação das políticas eminentemente públicas e daquelas de caráter estritamente empresarial.

$\S 2^{\circ}$ - A prestação anual de contas das entidades de Que trata este artigo será acompanhada de demonstrativo da remuneração paga aos respectivos consetheiros, bem como das atas das reuniōes realizadas durante o exercício.

$\S 3^{\circ}$ - Aos membros dos conselhos a que se refere este artigo é vedada:

I - a participação, a Qualquer título, nos lucros da cntidade;

II - (Vetado.)

$\S 4^{\circ}$ - (Netado.)

Art. $2^{\circ}$ - O art. 119 da Lei 8112 , de 11 de dezembro de 1990, passa a vigorar acrescido do seguinte parágrafo único:

Art. 119 - (O servidor não poderá exercer mais de um cargo em comissão, exceto no caso previsto no parágrafo único do art. $9^{\circ}$, nem ser remunerado pela participaçã̉o em órgão de delíberação coletiva.)

Parágrafo único - O disposto neste artigo não se aplica à remuneraçắo devida pela partícipação em Conselhos de Administraçăo e Fiscal das empresas públicas e sociedades de economia mista, suas subsidiárias e controladas, bem como quaisquer entidades sob controle direto ou indireto da Uniâa, observado o que, a respeito, dispuser lcgislaçăo específica. Art. $3^{\circ}$ - Compete aos órgãos integrantes do Sistema de Controle Interno do Poder Executivo e aos conselheiros fiscais zelar pelo cumprimento do disposto nesta Lei.

Art. $4^{\circ}$ - Esta Lei entra en vigor na data de sua publicação.

Art. $5^{\circ}$ - Revogam-se a leei 7.733 , de 14 de fevereiro de 1989. e as demais disposiçōes em contrário. (Grifo nosso.)

Disciplinamento que fol regulamentado pelo Decreto $\mathrm{n}^{\circ}$ 1.957, de 12.07.96:

Art. $1^{\circ}$ É vedada a participação remunerada de servidores da Administraçăo Federal, direta ou indireta, em mais de dois consehhos, de administração ou fiscal, de empresas públicas e de sociedades de economia mista federais, bem como das demais entidades controladas direta ou indiretamente pela Uniăo.

Art. $2^{\circ}$ Este Decreto entra em vigor na data de sua publicação. (Grilo nosso.) 
4. É mister, nesse contexto, até por Questões de ordem prática, Que se restabeleça a remuneração dos servidores da Administração Federal direta ou indireta como membros dos conselhos de administração e fiscal das empresas estatais, vedada pela Lei $n^{\circ} 7.733$, de 14 de fevereiro de 1989 , cuja revogação ora se propóe.

5. De outra parte, propõe-se, ainda, a inclusão de parágrafo único ao artigo I 19, da Lei 8.112, de 11 de dezembro de 1990, Que dispôe sobre o regime jurídico único dos servidores públicos civis da União, para adeQuá-la aos objetivos aqui pretendidos, uma vez Que, sem a modificação proposta, o projeto de lei em causa seria conflitante com aquele diploma legal, Que prołbe a remuneração pela participação em órgão de deliberação coletiva.

6. Para atender ao disposto nos artigos 152 e 162 , $3^{\circ}$, da Lei 6.404 , de 15 de dezembro de 1976, o aludido projeto de Lei fixa limites para a remuneração dos ditos conselheiros e veda, aos mesmos (...) a participação nos lucros como forma de retribuição pecuniária pelo seu exercício, tanto na condição de conselheiro de administração, como na de conselheiro fiscal.

7. Resguardados os princípios da ordem pública Que embasam as funções de administração e fiscalização de entidades federais, espera-se, com as disposiçōes contidas nesta proposição, manter e aprimorar o profissionalismo na composição dos ditos conselhos.

8. Assim, considerando o caráter meritório dos objetivos ora pretendidos, especialmente no tocante ao inadiável restabelecimento da justa compensação por serviços prestados pelos membros dos conselhos de administração e fiscal das empresas estatais, sugerimos o encaminhamento do anexo projeto de lei à consideração dos Senhores Membros do Congresso Nacional." (Diário do Congresso Nacional, Seção I, 3 1/08/94. Grifo nosso.).

Argüída a inconstitucionalidade dos artigos $2^{\circ}$ e $5^{\circ}$ da indigitada Lei federal $n^{\circ}$ 9.292/96, na ADIn no 1485-4-DF sob o argumento de acúmulo, este foi afastado pelo STF em sessão plenária, no julgamento do pedido de medida cautelar, sendo Relator o Ministro losé Néri da Silveira, em 07.08.96 (Dl de 16.08.96), em acórdão unânime, de cuja ementa consta:

5. Alega-se vulneração ao art. 37, XVI e XVII, da Constituição, Quanto à acumulação remunerada de cargos, empregos e funções públicas. 4 . Não se cuida do exercício de cargos em comissão ou de funções gratificadas, stricto sensu, especialmente porque se cogita, aí, de pessoas jurídicas de direito privado. 5. Não se configura, no caso, 
acumulação de cargos vedada pelo art. 37, XVI, da Lei Maior. 6. Não caracterização do pressuposto da relevância jurídica do pedido. 7 . Medida cautelar indeferida.

E na fundamentação do voto, o Relator salienta:

A Lei impugnada, ademais, em seu art. $1^{\circ}$, estipula Que a remuneração mensal devida aos membros dos conselhos de administração e fiscal das entidades aludidas 'não excederá, em nenhuma hipótese, a dez por cento da remuneração mensal média dos diretores das respectivas empresas'. É, também, vedada, a teor do $\$ 3^{\circ}$ do art. $1^{\circ}$, do Diploma, aos membros dos conselhos a que se refere a Lei no 9292 , a participação, a Qualquer título, nos lucros da entidade.

É exato, ainda, que ao servidor não é vedado o exerćcicio de função de chefia, cula retribuição, na forma da lei, se acrescenta à remuneração do cargo de provimento efetivo. Não se trata, então, de acumulação de cargos, vedada pelo art. 37. XVI, da Lei Maior. A observação cresce de ponto, no caso concreto, em que se disciplina exercício por servidor de função em conselho de entidade de direito privado, com remuneração que guarda antes caráter correspondente a retribuição de representação.

Assim sendo, nos limites de apreciação do feito, no júzzo cautelar, indefiro a liminar pleiteada. ${ }^{56}$

De interesse referir Que, após alteração da norma estatutária contida no art. 119 pela Lei federal no 9.527, de 10.12.9757, este artigo foi novamente modificado em 4.09 .01 , pela Medida Provisória no $2.225-45$, para possibilitar a atuação de servidores públicos federais em diversos entes da Administração indireta federal.

Também sucessivamente alterado o inciso X do art. I I7, ainda da mesma Lei federal no 8.1 12/90, de modo a compatibilizar a vedação estatutária, à nova redação do dispositivo transcrito, atualmente com a redação Que the foi conferida pela Lei $n^{\circ} 11.094$, de 13 de janeiro de 2005.58

56 Ação Que ainda pendente da apreciação de mérito, redistribuída ao Ministro Gilmar Ferreira Mendes em [3] $08 / 03$.

${ }^{57}$ Art. 119. O servidor não poderá exercer mais de um cargo em comissão, exceto no caso previsto no parágrafo único do art. $9^{\circ}$, nem ser remunerado pela participação em órgão de deliberação coletiva.

Parágrafo único. O disposto neste artigo não se aplica à remuneração devida pela participaçâo em consethos de administração e fiscal das empresas públicas e sociedades de economia mista, suas subsidiárias e controladas, bem como Quaisquer empresas ou entidades em que a Uniâo, direta ou indiretamente, detenha participação no capital social, observado o Que, a respeito, dispuser legislação especílica.

58 Art. 117 - Ao servidor é proibido: [...] X - participar de gerência ou administraçäo de sociedade privada, personilicada ou não personificada, salvo a participação nos conselhos de administração e liscal de empresas ou entidades em Que a União detenha, direta ou indiretamente, participação no capital social ou em sociedade cooperativa constituída por servidores públicos para prestar serviços a seus membros, e exercer o comércio, exceto na Qualidade de acionista, cotista ou comanditário; 


\section{A REPERCUSSÃo PREVIDENCIÁRIA dA REMUNERAÇÃo PAGA AOS MEMBROS DE COLECIADOS}

Se o agente público, submetido a regime previdenciário próprio, estiver autorizado à percepção de jeton por sua legislação de regência, esse, em geral, é excluído da base de cálculo da contribuição (pelo disciplinamento do regime previdenciário próprio), porque tal atividade é desvinculada da remuneração de seu cargo efetivo, ainda que seja deste decorrente, em face da co-relação entre as atribuições exercidas na origem com as atividades desempenhas no colegiado. Atividades estas Que, consoante já analisado, têm natureza de múnus público, categorizadas para o servidor público como comissões legais, sendo assim admitidas por seus estatutos. Dessa forma, o valor auferido pela participação nesses órgãos - jeton constitui gratiflcação pelo trabalho extraordinário prestado ao Poder Público a Que o agente público está funcionalmente vinculado. Razão por Que, nesse caso, permanece filiado apenas ao regime previdenciánio próprio, isto é, ao regime instituído pelo ente político no exercício da competência definida pelo $\$ 1^{\circ} \mathrm{do}$ art. 149 (correspondente ao parágrafo único da redaçấo original), combinado com o art. 25 , ambos da CRFB.

Normas reafirmadas na preceituação constante do atual $\S 13$ do art. 40 da mesma Carta, ao definir a filiação ao Regime Geral de Previdência Social apenas daqueles que desempenhem, com exclusividade, atividades temporárias ${ }^{59}$.

Entretanto, se o pagamento do jeton não estiver categorizado como gratificação e assim autorizado e disciplinado, necessário considerar as disposições constantes dos planos de custeio e de benefícios da Previdência Social, expressas no $\S I^{\circ}$ do art. 13, combinado com o disposto na alinea ' $f$ ' do inciso $V$ do art. 12 da Lei 8.212 , e $\$ 1^{\circ}$ do art. 12 , combinado com a disposição contida na alínea 'f' do inciso $V$ do art. 11 da Lei 8.213 , ambas da mesma data de 24 de jutho de 1991 . Disposições vigentes na forma conferida pela Lei 9.876, de 26 de novembro de 1999, Que, respectivamente, prevêem a concomitância de atividades exercidas pelo servidor ou militar e a filiação ao Regime Geral de Previdência Social, na categoria de contribuinte individual, como "membro de conselho de administração de sociedade anônima", sendo definido como salário-de-contribuição, para essa categoria de contribuinte, "a remuneração auferida em uma ou mais empresas", nos termos do inciso III do art. 28 da Lei $8.212 / 91$, com a redação alterada também pela Lei $n^{\circ} 9.876$, de 26 de novembro de 1999.

Previstas a mesma filiação e a mesma incidência no $\S 1^{\circ}$ do art. 10 , combinado com a alínea ' $f$ ' do inciso $V$ do art. $9^{\circ}$ do Decreto $n^{\circ} 3.048$, de 6 de maio de 1999, ambas as disposições na redação conferida pelo Decreto no 3.265, de 29.11.1999.

${ }^{59}$ Delúbio Gomes Pereira da Silva in Regime de previdência social dos servidores públicos no Brasil: perspectivas. Sāo Paulo:LTr, 2003, ps. 76-80, e Wladimir Novaes Martinez in Reforma da previdência social - comentários à Emenda Constitucional $n^{\circ}$ 20/98. Săo Paulo:LTr, 2003, p. 67. 
Ainda prevista a filiação ao RGPS do membro de conselho fiscal de sociedade por ações, conforme inciso $V$ do $\S 15$ do art. $9^{\circ}$ do Decreto $n^{\circ} 3.048 / 99$.

Disposições Que terão incidência se concretizada a hipótese legal, como anota Sérgio Pinto Martins:

Atualmente, a lei previdenciária considera os membros do Conselho de Administraçãa na sociedade anônima como empresários. Contudo, é possivel que uma sociedade por cotas de responsabilidade limitada tenha conselho de Administração, porém a legislação previdenciária não menciona a sua condição, Que poderia ser equiparada à do conselheiro da sociedade anônima, por analogia. Entretanto, o contribuinte deve ser definido em lei, sendo Que o emprego da analogia não poderá resultar na exigência de tributo não previsto em lei $\left(\S 1^{\circ}\right.$ do art. 108 do CTN). Assim, o membro do Conselho de Administração de sociedade por cotas de responsabilidade limitada não será contribuinte ou empresário para os efeitos da seguridade social. ${ }^{60}$ (Grifo nosso.)

Esse Questionamento, somado à constatação de Que também inexiste previsão - na legislação previdenciária - de filiação do membro de conselho fiscal, parece comprometer a aplicação de tais disposições, Quanto à incidência da contribuição previdenciária sobre a remuneração auferida pelos membros dos colegiados integrantes de entidades não especificadas, porque necessariamente restrita às hipóteses expressas nas mencionadas Leis.

Ademais, seria estranhável a filiação previdenciária - ao RGPS - do servidor em face do desempenho de um encargo Que decorre (direta ou indiretamente) de sua vinculação originária, mormente Quando permanece no desempenho de suas atribuições funcionais e filiado a seu regime previdenciário próprio. Situaçâo Que parece desconforme aos princípios determinantes da manutenção do servidor, exclusivamente no regime previdenciário próprio, durante afastamentos sem ônus para a origem sendo remunerado por outras fontes. ${ }^{61}$

60 Direito da Seguridade Social. $17^{\text {a }}$ ed., Săo Paulo: Editora Atlas S.A., 2002, p. 126. A doutrina é uniforme Quanto à exigência de prévia e expressa definição legal da incidência contributiva, podendo ser citados exemplificativamente: Wladimir Novaes Martinez, in O salário-de-contribuição na lei básica da Previdência Social. Săo Paulo: LTr., 1993, p. 109; Simone Barbisan Fortes e Leandro Paulsen, in Direito da Seguridade Social: prestações e custeio da previdência, assistência e saúde. Porto Alegre: Livraria do Advogado Ed., 2005, ps. 350-351; Bernardo Ribeiro De Moraes in Compêndio de Direito Tributário. $3^{a}$ ed., Rio de laneiro: Forense, 1997. p. 96.

${ }^{61}$ Orientaçâo Normativa $n^{\circ} 03$, de 13 de agosto de 2004, expedida pela Secretaria do Ministério de Previdência Social, no uso das atribuiçōes de orientação, supervisão e acompanhamento dos regimes próprios de previdência social dos servidores públicos e dos militares da União, dos Estados, do Distrito Federal e dos Municípios, definidas pelo inciso 1 do art. $9^{\circ}$ da Lei federal $n^{\circ} 9.717$, de 27 de novembro de 1998 : $[\ldots]$ 


\section{A DISTINÇÃO ENTRE CARGOS, EMPREGOS, FUNÇŌES E A PARTICIPAÇÃO EM COLEGIADOS DA ADMINISTRAÇÃO DIRETA E INDIRETA}

Pelo exposto, verifica-se Que a remuneração não modifica a natureza da participação do servidor no colegiado, como salientado pelo Ministro Themístocles Brandão Cavalcanti no acórdão já referido, correspondente ao MS n ${ }^{\circ} 18.697-D F$ de $21 / 05 / 69$, onde esclarece:

[...] no serviço público, a Constituição em seus arts. $95 \S \S 1^{\circ} \mathrm{e} 2^{\circ} \mathrm{e} 104$ [Constituição do Brasil, de 24/0!/67], só prevê três categorias de funcionários, a saber:

"Os nomeados por concurso; os nomeados em comissão regulados peła legislação específica; e os servidores temporários para obras ou contratados para funções de natureza técnica e regulados pela Consolidação das Leis do Trabalho".

Não haveria lugar para funcionários nomeados pro tempore, porque não prevista no texto constitucional.

O equívoco porém, está em equiparar funcionários públicos aos Que exercem funções temporárias, sem as Qualificações do funcionário.

Há muito que faço essa distinção (ver nosso Tratado de Direito Administrativo, V:20 - O Funcionário Público e o seu Regime /urídico, 1:30). Não exercem funções, mas encargo público - Bielsa, Zanobini, chamariam carga pública".

A lei veio consolidar esse conceito doutrinário. Funcionário público é o Que exerce cargo público e cargo público, di-lo a Lei n 3.780 , de 1960, ratificando as definições de toda a legislação anterior:

"É o conjunto de atribuições e responsabilidades cometidas a um funcionário, mantidas as características de criação por lei, denominação própria, número certo e pagamento pelos cofres públicos" (Suplemento do Tratado-V:242).

Não só isto, também a permanência, a continuidade, a integração ao sistema administrativo caracterizam a Qualidade de funcionário.

Art. 13. O servidor público titular de cargo efelivo da União, Estados, Distrito Federal e Municípios filiado a regime próprio permanecerá vinculado ao regime de origem nas seguintes situações:

l - Quando cedido a órgão ou entidade da administraçăo direta e indireta de outro ente federativo, com ou sem ônus para o cessionário;

II - Quando licenciado, observando-se o disposto no art. 3 I [condiciona o cômputo do tempo de serviço ao recolhimento quando o afastamento se dá sem remuneraçäo];

Ili - durante o afastamento do cargo efetivo para o exerć́cio de mandato eletivo;e

IV - durante o afastamento do país por ceșão ou licenciamento com remuneração.

Parágrafo único. O segurado exercente de mandato de vereador que ocupe, concomitantemente, o cargo efetivo e o mandato filia-se ao regime próprio, pelo cargo efetivo, c ao RGPS, pelo mandato eletivo. 
É o Que está no Estatuto dos Funcionários Públicos, era o Que constava como definição precisa de todos os projetos de estatutos, desde o de Gracho Cardoso em 1911, é a opinião de todos os nossos autores, desde Viveiros de Castro e Alcides Cruz até Hely Lopes Meirelles e Cretella Júnior. Foi sempre o Que sustentei, isto é, Que a permanência, a continuidade no serviço é Que caracterizam o funcionário público.

É a jurisprudência francesa e italiana Que sempre acompanhamos e a doutrina daqueles países, como se vê, em Berthélemy, Staninof, Kammarer, e os mais modernos como Waline, Laubadère, Zanobini, e tantos outros que seria longo enumerar.

Assim, aquele que é nomeado pro tempore para exercer determinada função pública, não é, nem sequer servidor público em seu sentido próprio, embora, em sentido genérico e usual, não se the possa negar essa Qualidade, desde Que nessa categoria se incluam os Que exercem meras funções públicas, mas mediante contribuição [retribuição] por sessão do conselho de Que participam e a Que comparecem.

E acrescenta adiante: "A Constituição não previu nem precisava cogitar da espécie porque, no caso, se trata de mera colaboração com a administração pública e não de servidor público."

Distinção ineliminável, considerando Que servidores públicos, são "todos aqueles Que mantêm com o Poder Público relação de trabalho, de natureza profissional e caráter não eventual, sob vínculo de dependência" conforme Celso Antônio Bandeira de Mello. ${ }^{62}$ No mesmo sentido, Ivan Barbosa Rigolin, citando Adilson Abreu Dallari, destaca os fatores de profissionalidade, isto é dependência econômica, habitualidade, ou não eventualidade, e subordinação. ${ }^{63}$ Características inexistentes na atividade em foco.

E Ruy Cirne Lima definitivamente esclarece:

Quatro caracteristicas, independentes entre si, sinalam o funcionário público profissional: a) natureza técnica ou prática do serviço prestado; b) retribuição

62 Regime constitucional dos servidores da Administraçăo Direta e Indireta, São Paulo: Revista dos Tribunais. 1990, p. 9.

${ }^{63}$ O Servidor Público na Constituição de 1988, São Paulo: Ed. Saraiva, 1989, p. 80. E adiante enfoca a remuneração dos servidores enfatizando: "[...] a proibição de a Administração manter servidor a título gratuito. A relação profissional é, antes que nada mais, onerosa, cabendo lembrar o texto dos incs. IV, V. VI, VII, além de outros aplicáveis aos servidores, todos do art. $7^{\circ} \mathrm{da}$ carta, Que asseguram a percepção de remuneração pelo trabalhador em razâo de seu trabalho. De resto os estatutos de funcionários também, em geral, fixam a proibição de trabalho gratuito, como é o caso do estatuto federal, a Lei $\pi^{\circ} 1.711$, de 28 de outubro de 1953, Que no art. $4^{\circ}$ determina: 'É vedada a prestação de serviços gratuitos'[...]. Serviço gratuito, a Administração o pode ter nâo de servidores, mas, como se verá, de particulares em desempenho de missão ou função descrita como honorífica, ou de relevante interesse ou utilidade pública, como em comissões, júri, missões diplonáticas ou culturais, e outras hipóteses." 
de cunho profissional. c) vinculação jurídica à União, Estado, ao distrito Federal ou ao Município; d) o caráter permanente dessa vinculação, segundo uma disciplina legal específica. ${ }^{64}$ (Grifo nosso.)

Atuação também inconfundível com o exercício de cargos em comissão Que, conforme preceituação constitucional, devem ter atribuições de direção, chefia e assessoramento (CRFB, art. 37, $\mathrm{V}$, em sua atual redação; CE/89, art. 32), com jornadas diárias, portanto contínuas, e cargas horárias mínimas, mediante remunerações correspondentes, portanto sujeitos a condições de trabalho similares às dos demais servidores submetidos às regras estatutárias.

Distinta também daqueles que titulam funções, como se verifica pelos ensinamentos de Maria Syvia Zanella Di Pietro, ao enfocar as alterações sofridas pelo termo 'função' e concluir:

Portanto, perante a Constituição atual, Quando se fala em função, tem-se Que ter em vista dois tipos de situações:

1. a função exercida por servidores contratados temporariamente com base no artigo 37, IX, para as Quais não se exige, necessariamente, concurso público, porQue, às vezes, a própria urgência da contratação é incompativel com a demora do procedimento; (...)

2. as funções de natureza permanente, correspondentes a chefia, direção, assessoramento ou outro tipo de atividade para a qual o legislador não crie o cargo respectivo; em geral, são funçôes de confiança, de livre provimento e exoneração; a elas se refere $o$ art. $37, \mathrm{~V}$, ao determinar Que "os cargos em comissão e as funções de confiança serão exercidos, preferencialmente, por servidores ocupantes de cargo de carreira técnica e profissional, nos casos e condições previstos em lei". Também se faz referência a elas no art. 19. § $2^{\circ}$, das disposições transitórias para excluí-las da estabilidade excepcional concedida por esse dispositivo. ${ }^{65}$

Coincidente é o entendimento de Celso Ribeiro $\operatorname{Bastos}^{66}$ e de Diogo de Figueiredo Moreira Neto, este anotando:

2. Função pública. A idéla se liga à atividade que deverá ser desempenhada pelo servidor público civil. Essas atividades são ordenadas, especiálizadas e coordenadas, de modo a suprirem as necessidades operativas do serviço público. Cada uma dessas atividades se denomina atribuição. Uma função pública resultará, portanto, do cometimento de uma ou mais atribuições a alguém.

64 Princípios do Direito Administrativo, Porto Alegre: Sulina, 1964, p. 162.

6 Direito Administrativo, 9* ed., Säo Paulo: Editora Atlas S.A.. 1998, p. 358-359.

as Curso de Direjto Administrativo, $3^{a}$ ed., São Paulo: Editora Saraiva, 1999, p. 283 
O Estatuto Federal não conceitua funçấo públicaem sentido autônomo, o que vale dizer que Quaisquer funções públicas às Quais não correspondam cargos especíícos, não estão a ele sujeitas, como o são, por exemplo, as de jurados, de mesários eleitorais, de escrivães e oficiais de justiça ad hoc, de tradutores juramentados etc. Esse Estatuto se refere, todavia, a funções públicas enQuanto conjuntos de atribuições acrescidas a cargos públicos, como as de direção, chefia e assessoramento (art. $38 \S \S 1^{\circ} \mathrm{e} 2^{\circ}$; art. 61 , 1; e art. 62).

A existência de função pública autônoma estatutária é incompativel com a obrigação constitucional de disposição em carreiras (art. 39, caput, CF). ${ }^{67}$ (Grifo nosso.)

Para Diógenes Gasparini:

As funções sem cargo ou autônomas, como Querem alguns, são provisórias, e, por essa razão, devem ser da responsabilidade de agentes temporários. Tampouco se confunde com emprego público. Este é o trabalho, o ofício, exercido por um servidor em caráter permanente, sob o regime da Consolidação das Leis do Trabalho. A diferença entre função e emprego público está na duraçăo do desempenho, isto é, naquela é temporário, neste é permanente.

Também não se confunde com função gratificada, Que é uma vantagem pecuniária, acessória do vencimento, criada por lei, paga ao servidor em razão de encargos de chefila, assessoria e de secretaria, consoante a dicção do att. $9^{\circ}$ da Lei federal $3.780 / 60 .^{68}$

Wolgran Junieueira Ferreira também conclui: "Há funções sem cargos, mas sem estes inexiste fixação do servidor" ${ }^{69}$

Evidencia-se assim que o encargo ou múnus público correspondente à participação em colegiados, por designação do poder público ou por via da eleição, não pode ser considerado equivalente a cargo, emprego ou função, ou contido nessas expressões ou nos conceitos a essas correspondentes, o Que se verifica tanto pela interpretação sistemática desses termos, como pela análise da participação em colegiados conforme sua natureza e suas características.

Com esse intuito, constata-se Que, em geral, essa atuação se desenvolve nas seguintes condiçōes:

- atividade intermitente, Que não se enQuadra nos parâmetros de carga horária ou jornada laboral dos servidores ou empregados Que mantêm vínculo profissional com os entes e órgãos da Administração Direta e Indireta;

\footnotetext{
67 Curso de Direito Administrativo, I $^{a}$ ed., Rjo de Janeiro: Editora Forense, 1997. p. 205-206.

${ }^{68}$ Direito Administrativo, 4a ed., São Paulo: Editora Saraiva, 1995, p. 187-188.

69 Comentários à Constituição de 1988, Ed. Jutex Livros, 1989, v. 1, p. 452.
} 
- regulação por normas específicas vigentes no ente ou órgão a cuja estrutura está vinculado o colegiado;

- temporariedade da atuação, limitada a períodos certos, correspondentes a mandatos;

- remuneração pelo comparecimento a reuniões, sob a forma de jeton, com caráter temporário, sem gerar dependência econômica;

- atuação integrativa de vontade coletiva - do colegiado.

Atuação Que, nesses mesmos aspectos, a diferencia do exercício em cargos em comissão, além de terem estes destinação limitada às atividades de direção. chefia e assessoramento, como já apontado.

\section{A COMPATIBILIDADE ENTRE AS ESSAS ATUAÇÕES (NO CARGo, EMPREGO OU FUNÇÃO NA ORIGEM E COMO MEMBRO DO COLEGIADO) E A CONSEQÜENTE INOCORRÊNCIA DA ACUMULAÇÃO CONSTITUCIONALMENTE VEDADA}

Ademais, observa-se que, sendo essas participações - em colegiados - intermitentes e sem jornada pré-determinada, sequer há suporte fático para incidência da regra constitucional referente à compatibilidade de horários, permissiva da acumulação, a demonstrar que a vedação constitucional concerne a institutos distintos, inconfundiveis com a atuação em foco.

Assim, inexistindo vedação específica abrangente de tais participações, inviável afirmar Que estas obrigariam ao afastamento da posição ocupada na Administração Pública, ainda porque, nesse caso, criar-se-ia verdadeira sinecura, afrontosa aos princípios da razoabilidade, da economicidade e da moralidade, mantendo-se a remuneração do cargo efetivo ou do emprego sem a correspondente atividade, sendo esta reduzida exclusivamente às sessóes periódicas do colegiado, conforme entendimento Que cumpre definitivamente afastar.

Como inviável seria a participação do servidor desprovida da remuneração, quando regularmente fixada para os membros dos órgãos de deliberação coletiva, porque esta é determinada pelo comparecimento às sessões, como direito correspondente ao desempenho de todos os seus integrantes.

Inexistente também ímpedimento à designação ou eleiçâo, para os colegiados, de servidor provido em cargo em comissão ou detentor de função gratificada. Impedimento que inocorre, porque, afastada a equivalência de tais posições, a base legal para pagamento do jeton de presença é inconfundível com o fundamento da remuneração do cargo em comissão ou da função gratilicada, mormente sendo o pagamento do jeton de presença admitido entre as vantagens previstas estatutariamente para o servidor público.

Ademais, de considerar Que, muitas vezes, é de interesse preferencial a participação no colegiado dos servidores Que, tendo maior Qualificação, experiência e mais informações, 
em decorrência do exercício das funções de chefia, de direção ou de assessoramento, se encontram mais habilitados a viabílizar a atuação coordenada dos diversos entes e órgãos da Administração, como salientam Ewan Ferlie et al:

As inter-relações dentro de tais grupos mistos são algumas vezes vistas em termos de uma ordem negociada (Hodgson et al., 1965; R. Stewart, 1991). Embora pequenos em tamanho, os conselhos dirigentes das organizações públicas incluem uma série complexa de papéis e inter-relações diferentes (por exemplo, a relação entre o presidente da empresa e o CEO lchief executive officiers $=$ dirigentes máximos de instituições públicas], entre o presidente da empresa e os diretores não executivos, entre os diretores executivos e os diretores não executivos).

Também gera impasses, o entendimento de Que a participação de empregados públicos em tais órgãos deliberativos determina a suspensão ou a interrupção do contrato de trabalho, sob o argumento de sua incompatibilidade com a subordinação inerente ao vínculo trabahista.

Entretanto, essa subordinação deve ser considerada com diferenciais inexistentes no setor privado.

O primeiro, decorrente da condição do empregador-poder público, integrante de uma estrutura organizacional com fins pré-estabelecidos em função do interesse público, submetido a um disciplinamento que elide a arbitrariedade e faz obrigatória a motivação de seus atos.

O segundo, em razão da condição do empregado público, admitido por concurso e contratado, conforme disciplinamento Que regula sua atividade funcional.

O terceiro, relacionado à qualificação pessoal, Que deve ser comprovada, e constitui pressuposto da designação ou da eleição, a dificultar a submissão indevida.

Outrossim, necessário considerar que as sociedades de economia mista, empresas públicas, subsidiárias e controladas pelo poder público devem ser por este direcionadas justamente para atingimento dos fins previstos na lei que autorizou a criação ou a aquisição da pessoa jurídica. Por conseqüência, resulta afastado o risco de indevida submissão do empregado aos desígnios do empregador, de modo a comprometer os interesses dos acionistas, pois, na situação enfocada, esses fins são legalmente Qualificados e submetidos à supervisão estatal, como já salientado. Situação em que essa convergência de vontades é instrumental da ação administrativa e, portanto, imprescindivel.

Fatores Que compõem uma situação jurídica diferenciada, em face de condições inexistentes no setor privado, e que levam a conduir pela compatibilidade entre a condiçăo de empregado de ente da Administração Indireta e sua participação em colegiados, por designação do poder público ${ }^{70}$.

* No Parecer PGE no 8.756/91, a Procuradora do Estado do Rio Grande do Sul Clarita Gałbinski observa: "4. $\mathrm{Na}$ prestação de serviços públicos, às vezes o Estado lança mão de seus setores da Administração Direta e, 
De salientar, porém, Que sua designação deve ser precedida da consulta e da aQuiescência do empregado, sob pena de configurar-se indevida alteração do ajuste laboral, e da autorização expressa do empregador, por intermédio dos órgãos para tanto competentes, na forma do seu disciplinamento interno .

Aspectos Que poderiam causar estranheza se os demais entes da Administração não estivessem na mesma contingência de necessitar de recursos humanos para compor seus órgãos estruturais, como o consetho fiscal, nas sociedades de economia mista, o conselho curador nas fundaçōes, etc.. Do que resulka um verdadeiro intercâmbio de recursos humanos como instrumental necessário à própria existência de tais entes e órgãos, portanto, de interesse público, categorizado como múnus público, a justificar o deslocamento do agente de sua posição na origem.

\section{A NECESSÁRIA LIMITAÇÃo DE TEMPO DE MODO A NÃO PREJUDICAR O DESEMPENHO DO CARGO, EMPREGO OU FUNÇÃO NA ORIGEM, CASO AS SESSÕES DO COLEGIADO SEJMM REALIZADAS NO HORÁRIO DE EXPEDIENTE}

Pelo exame das normas referidas, verifica-se Que, tanto em âmbito federal como em âmbito estadual, existem limitações à participação dos servidores da Administração Direta e Indireta em colegiados. Assim, o Decreto Federal $n^{\circ} 1.957 / 96$, Que regulamentou $o$ art. 119 da Lei federal no 8.112/90, com a redação conferida pela Lei n $n^{\circ} 9.292 / 96$, vedou a participação de servidores em mais de dois colegiados.

Ao passo que a Lei n $n^{0}$ 7.369/80 do Estado do Rio Grande do Sul, estabelece, no artigo $3^{\circ}$, o número máximo mensal de Quinze reunióes remuneradas para cada membro, "excetuados os do Conselho Estadual de Educação, cujo limite será de vinte e quatro" e, no artigo seguinte a impossibilidade de os servidores integrarem mais de um órgão de deliberação coletiva.

Admitida a participação do servidor nos colegiados durante o horário de expediente, impende considerar que embora sua atuação seja de interesse público, como enfatizado, o afastamento Que comprometa o desempenho do exercício do agente em suas funções na

em outros, da Administração Indireta, aparecendo hipóteses em que, necessitando contar com o auxilio técnico de determinado agente, o Poder Público formaliza convite para empregado vinculado a sociedade de economia mista, empresas públicas ou fundaçôes. 5. Não se tratando de requisiçâo, fica a critério do representante da pessoa jurídica ceder ou não ceder o servidor, $e$, ademais, na dependência de manifestação de vontade do último, Que só se deslocará para a Administraçăo centralizada querendo e desde que não lhe advenha, direta ou indiretanente, Qualouer prejuizo. Este é um exemplo típico de influência do direito Público nas relaçóes privadas mantidas entre a sociedade de economia mista (que é o caso indagado nos autos) e o seu empregado. 6. Vale-se o empregador, na hipótese, da ligura prevista no artigo 472 da Consolidação das Leis do Trabalho, [...]". 
origem deve ser coibido, porQue neste caso a percepção integral de sua remuneração resultaria em um ganho sem contraprestação.

Assim, para Que seja assegurada a efetividade dos princípios de economicidade, moralidade e eficiência, conveniente a limitação do tempo de afastamento necessário para comparecimento às sessões, o número máximo de colegiados Que podem ser integrados pelo mesmo agente público e o número máximo de sessôes mensais, regramento Que pode ser editado pelo ente político, no exercício de sua competência administrativa.

De ressalvar Que, os Conselhos Tutelares, Quando a participação é remunerada e há dedicação integral, são exemplos de órgãos com tipicidade própria, Que não se enQuadram na regra geral da compatibilidade com a função exercida na origem ${ }^{71}$.

\section{CONCLUSÕES}

1. Os colegiados, em suas diversas espécies e com diferentes funçōes, constituem forma amplamente adotada pela Administração Pública Direta e Indireta, sendo imprescindiveis tanto à estruturação e ao controle das entidades Que a integram Quanto à composição de interesses, na busca da consensualidade para prevenção de conflitos.

2. Nas sociedades de economia mista, instrumentalizam o controle e a orientação para concretização dos fins legalmente definidos pelo acionista controlador.

3. A investidura nesses órgãos de deliberação coletiva, viabilizando tanto a estruturação da pessoa jurídica e, conseqüentemente, o atingimento de seus fins, como a busca de soluções baseadas na ponderação do juízo coletivo, tem a natureza de múnus público, resultando de atribuições com caráter de comissão legal, para os Que já detêm a condição de agentes públicos, e na Qualificcação de agentes honorílicos para os demais.

4. Para atingimento das funções cometidas a tais órgãos e para sua atuação em padrões de moralidade e eficiência, importa, na escolha de seus integrantes, prioritariamente a adeQuação, condicionada à satisfação dos requisitos necessários e à forma da investidura de acordo com o sistema adotado, se por designação, por eleição ou pela combinação de ambos. Sistemas que determinam o grau de tecnicidade e de representatividade do colegiado.

5. Conforme posicionamento adotado pelo Supremo Tribunal Federal, a temporariedade prevista dessa investidura, fixada em mandatos, pode ser reduzida se a função do colegiado é meramente administrativa.

\footnotetext{
"Nesse sentido o Parecer PGE $\mathrm{n}^{\circ} 9.620 / 93$, disponível no no site <http:/www.pge.rs.gov.br >. embora de considerar o disposto pelo art. 25 da $\mathrm{LC} \mathrm{n}^{\circ} 10.098$, de 03 de fevereiro de 1994 , e pelo Decreto $\mathrm{n}^{\circ}$ 36.603, de 11 de 11 de abril de 1996, do Estado do Rio Grande do Sul, que dispöem sobre a cedência e a colocação à disposição, normas disponíveis no site http://www.al...rs.gov.br .
} 
6. A remuneração dessa atividade, se prevista nas normas que disciplinam o colegiado, tem a forma de jețon, e terá a natureza de gratificação, se também prevista nos estatutos dos servidores Que o compóem, como vantagem admitida. Em caso contrário, embora a todos devida, não terá a tipicidade de gratificação.

7. O jeton só integra a base de cálculo de contribuição previdenciária mediante previsão legal expressa Que defina precisamente a hipótese ocorrente, não sendo possível a imposição contributiva com base na analogia.

8. As características dessa atuação e a especificidade de seu regramento determinam distinções necessárias eue a diferencia da atividade exercida no desempenho de cargos, empregos e funções, como enfatiza Themístocles Brandão Cavalcanti, mencionando projetos elaborados desde 1911, antiga doutrina nacional e alienígena. Características Que permanecem e são reafirmadas pelos atuais doutrinadores e pelo Supremo Tribunal Federal, em recente julgado.

9. Conseqüentemente, sendo incogitável a acumulação, porque inexistente um dos termos para que se configure a duplicidade constitucionalmente vedada, é possivel a participação do agente público em colegiados sem afastamento de suas funções na origem.

10. Para Que seja assegurada a eletividade dos princípios de economicidade, moralidade e eficiência, conveniente a limitação do tempo de afastamento necessário para comparecimento às sessões, o número máximo de colegiados Que podem ser integrados pelo mesmo agente público e o número máximo de sessões mensais, em disciplinamento Que pode ser editado pelo ente político, no exercício de sua competência administrativa. Norma Que será aplicável aos servidores Que, na origem, estão vinculados a órgãos públicos e que poderá servir de parâmetro aos demais.

\section{REFERÊNCIAS BIBLIOGRÁFICAS}

ARANOVICH, Rosa Maria de Campos. Parecer PGE/RS n ${ }^{\circ}$ 8.900/91, disponível no site $<$ hittp://www.pge.rs.gov.br >.

BANDEIRA DE MELlo, Celso Antônio. Prestação de serviços públicos e Administração Indireta. São Paulo: Ed. RT, 1973.

BANDEIRA DE MELLO, Oswaldo Aranha. Princípios gerais de direito administrativo. $2^{\mathrm{a}}$ ed., Rjo de laneiro: Ed. Forense, 1979.

BASTOS, Celso Ribetro. Curso de Direito Administrativo. $3^{a}$ ed., São Paulo: Ed. Saraiva, 1999.

BORBA, José Edwaldo Tavares. Direito societário. $3^{a}$ ed. revista e atualizada, Rio de Janeiro: Freitas Bastos Editora, 1997. 
CARNEIRO, Alaim de Almeida. Cargos em comissão. Revista de Direito Administrativo V. 17, julho-setembro-1949.

CARVALHOSA, Modesto. Comentários à Lei de Sociedades Anônimas. ed. revista e atualizada, São Paulo: Editora Saraiva, 1998.

CAVALCANTI. Themístocles Brandão. Tratado de Direito Administrativo. $2^{\text {a }}$ ed. revista e aumentada, Rio de Janeiro: Livraria Editora Freitas Bastos, 1948, v. I.

CIRNE LiMA, Ruy. Princípios do Direfto Administrativo. Porto Alegre: Sulina, 1964.

CRETELLA fr., José. Comentários à Constituição de 1988. $2^{\text {a }}$ ed., Rio de Janeiro: Forense Universitária, 1994.

. Direito Administrativo brasileiro. 2a ed., Rio de Janeiro: Forense, 2000.

DI PIETRO, Maria Sylvia Zanella. Direito Administrativo. 9a ed.,São Paulo, Atlas, 1998.

DIEZ, Manuel Maria. Derecho Administrativo, Buenos Aures: Bibliográfica Omeba, 1963.

ENTERRÍA, Eduardo Garcia. La organizacion y sus agentes: revisión de estructuras in La administración pública y el estado contemporaneo, Instituto de Estudios Politicos, Madrid: 1961.

FERLIE, Ewan et al. A nova administração pública em ação. Brasília: Editora Universidade de Brasília: ENAP, 1999.

FERREIRA, Aurélio Buarque de Holanda. Novo dicionário Aurélio da língua portuguesa, p. 1.172.

FERREIRA, Wolgran Junqueira. Comentários à Constituição de 1988. Ed. Julex Livros, 1989, vol. I.

FIGUEIREDO, Lúcia Valle. Empresas públicas e sociedades de economia mista. São Paulo: Ed. Revista dos Tribunais, 1978.

FIGUEIREDO, Pedro Henrique Poli de. ENCONTROS REGIONAIS DE CONTROLE E ORJENTAÇÃO promovidos pelo Tribunal de Contas do Estado do Rio Grande do Sul nos dias I 2, 25 e 25 de setembro de 2003, nas Cidades de Santa Cruz. Santa Maria e Erechim, em palestras proferidas sobre o Tema Terceirização no Serviço Público.

FONSECA, Tito Prates da. Direito Administrativo. Rio de lanciro: Livraria Editora Freitas Bastos, 1939.

FRANCO SOBRNNHO, Manoel Oliveira. Atos Administrativos, São Paulo: Edição Saraiva, 1980.

GASPARINI, Diógenes. Direito Administrativo. 4a ed., São Paulo: Ed. Saraiva, 1995.

GIANNINI, Massimo Severo. Instituzioni di Diritto Amministrativo, Milano: Dott. A. Giuffré Editore, 1981.

CIRNE LIMA, Ruy. Princípios do Direito Administrativo, Porto Alegre: Sulina, 1964.

MARIN, Iosé Gascon y. Tratado de Derecho Administrativo: princípios da legislación española. $6^{a}$ ed. revisada, Madrid: 1935. 

Atlas S.A.

MARTINS, Sérgio Pinto. Direito da Seguridade Social. $17^{a}$ ed., São Paulo: Editora

MEDAUAR, Odete. Direito Administrativo Moderno. 3a ed., Säo Paulo: Ed. Revista dos Tribunais, 1999.

MEIRELLES, Hely Lopes. Direito Administrativo brasileiro. $21^{\text {a }} \mathrm{ed}$., São Paulo: Malheiros Editores, 1996.

MENEGALE, 1. Guimarães. Conselho Administrativo da Caixa Econômica Federa - mandato por nomeação, do Presidente - sua coincidência com o dos conselheiros - indemissibilitidade "ad nutum". Revista Forense, v. 193, 1961.

MINISTÉRIO DA EAZENDA. Imposto de renda "jeton" de presença - diárias. Revista de Direito Administrativo, RV/SP, v. 73, p. 37I. 1963.

MONCH, Maria da Conceição do Amaral. As sociedades de economia mista e as empresas públicas: controle e responsabilidade. Revista de Direito Administrativo, Rio de laneiro, v. 127 , p.574, janeiro-março, 1977.

MOREIRA Neto, Diogo de Figueiredo. Uma nova administração pública. Revista de Direito Administrativo, v. 220.

PONDÉ, Lafayete. Peculiaridades do órgão colegiado. Revista do Tribunal de Contas do Estado de São Paulo n ${ }^{\circ} 32,2^{\circ}$ semestre de 1972, p. 122-133.

. Peculiaridades do órgão colegial. Revista de Direitto público, v. 20, p. 25-31.

RIGOLIN, Ivan Barbosa. O Servidor público na Constituição de 1988. São Paulo: Ed. Saraiva, 1989.

SILVA. De Plácido e. Vocabulário Jurídico, Rjo de laneiro: Forense, 1984, v. 1.

SILVA, Delúbjo Gomes Pereira da. Regime de previdência social dos servidores públicos no Brasil: perspectivas. São Paulo: LTr, 2003.

SILVA, José Afonso. Curso de Direito Constitucional positivo. $6^{\mathrm{a}}$ ed., $2^{\mathrm{a}}$ tiragem, São Paulo: Editora Revista dos Tribunais, 1990. 